\title{
Kepailitan Terhadap Anak Perusahaan dalam Holding Company Badan Usaha Milik Negara
}

\author{
Chintya Dewi Restyana S, Nikmah Mentari dan Sri Eka Wulandari \\ Fakultas Hukum Universitas Airlangga \\ Jln. Dharmawangsa dalam Selatan, Airlangga, Gubeng, Surabaya, Jawa Timur \\ chintyadewirest@gmail.com, nikmahmentari4@gmail.com, \\ sriekawulandarii@gmail.com
}

Received: 13 Maret 2019; Accepted: 17 Mei 2019; Published: 22 Agustus 2019

DOI: 10.20885 /iustum.vol26.iss2.art7

\begin{abstract}
Bankruptcy is a risk that can occur to both a subsidiary or a parent company in a state-owned holding enterprise. It is not a trivial matter for the state-owned holding company if its subsidiary suffers from bankruptcy, considering the position of the subsidiary and the parent company are separated, yet in some cases, the subsidiary is instead treated equally as a state-owned enterprise. The first issue would be, what is the legal relationship between the parent company and its subsidiary in the state-owned holding company; and second, how is the responsibility towards the bankrupted subsidiary. This research uses the normative juridical method. In which, it is concluded that first, as separate and independent entities, both the parent company and its subsidiary are restricted by the nature of separate legal entities and limited liabilities in carrying out their respective activities, even though they are bound under the same holding company. Second, the bankruptcy of a subsidiary of the state-owned holding company can occur and the responsibility of the parent company is limited to the shares that it owns, and if it is discovered that in its financial management, the parent company contribute in the bankruptcy of the subsidiary, then the responsibilities can expand.
\end{abstract}

Keywords: Bankruptcy; holding; state-owned enterprise; subsidiary

\section{Abstrak}

Kepailitan merupakan resiko yang dapat terjadi baik terhadap induk perusahaan maupun anak perusahaan dalam suatu holding company BUMN. Apabila anak perusahaan yang mengalami pailit, selaku holding company BUMN bukan persoalan sepele menghadapi kemungkinan tersebut, karena kedudukan anak perusahaan dan induknya yang terpisah, namun dalam beberapa hal, anak perusahaan BUMN diperlakukan sama halnya seperti BUMN. Permasalahan pertama, bagaimana hubungan hukum perusahaan induk dan anak perusahaan dalam holding company BUMN, dan kedua, bagaimana tanggung jawab terhadap anak perusahaan yang pailit. Metode penelitian ini ialah yuridis normatif. Penelitian ini menyimpulkan, pertama, meskipun terbentuk holding company, akan tetapi induk perusahaan dan anak perusahaan sebagai perusahaan yang terpisah dan mandiri dalam melakukan kegiatannya masing-masing dibatasi dengan adanya separate legal entity dan limited liability. Kedua, kepailitan anak perusahan yang termasuk dalam holding company BUMN dapat terjadi dan bentuk tanggung jawab induk perusahaan yang merupakan BUMN adalah sebatas dari saham yang dimilikinya dan apabila diketahui bahwa dalam pengelolaan manajemen keuangan, induk holding BUMN turut serta mengakibatkan anak perusahaan pailit, maka tanggung jawab dapat meluas.

Kata-kata Kunci: Kepailitan; anak perusahaan; holding; BUMN 


\section{Pendahuluan}

Pertumbuhan ekonomi negara diiringi dengan badan-badan usaha yang mulai bermunculan dan menunjukkan eksistensinya. Badan-badan usaha yang dimiliki oleh negara dikenal dengan Perusahaan Perseroan (Persero) dan Perusahaan Umum (perum). Persero merupakan salah satu bentuk badan usaha negara, tetapi ditundukkan kepada ketentuan-ketentuan hukum yang berlaku untuk Perseroan Terbatas (PT). ${ }^{1}$

Meskipun tunduk pada Undang-Undang Nomor 40 Tahun 2007 tentang Perseroan Terbatas (UU PT), akan tetapi, karena kekhususannya sebagai Badan Usaha Milik Negara (BUMN), maka tidak terlepas pula tunduk pada UndangUndang Nomor 19 Tahun 2003 tentang Badan Usaha Milik Negara (UU BUMN). Hal ini disebut sebagai sinergitas dan harmonisasi regulasi yang saling mengisi dan melengkapi suatu produk dalam tataran hukum yang bijak.

Tujuan dibentuknya BUMN juga untuk mengurangi ketergantungan terhadap Anggaran Pendapatan dan Belanja Negara (APBN) sekaligus sebagai pengejawantahan dari Pasal 33 UUD NRI 1945 tentang Perekonomian dan Kesejahteraan Sosial. Pasal 33 ayat (2) dan ayat (3) UUD NRI 1945 kemudian diimplementasikan dalam wujud BUMN, karena memang sektor penting negara dan hajat hidup orang banyak menjadi sasaran objek bisnis BUMN.

Seperti halnya dengan Perseroan lain yang berharap dapat memperkokoh kegiatan bisnisnya, BUMN sebagai badan usaha turut melebarkan sayapnya untuk menguasai sektor pasar dibeberapa bidang, baik sejenis maupun tidak sejenis. Kondisi inilah yang kemudian mendorong dibentuknya holding company. Seperti akhir-akhir ini telah dibentuk holding perusahaan tambang yang meliputi PT. Antam Tbk, PT. Bukit Asam Tbk, dan PT. Timah Tbk yang berada di bawah holding company PT. Inalum (Persero) yang sama-sama merupakan perusahaan tambang.

BUMN lainnya justru ada yang lebih awal melakukan holding company, seperti PT. Pupuk Indonesia (Persero) yang membawahi sekitar 10 anak perusahaan. Anak perusahaan tersebut antara lain PT. Petrokimia Gresik (PKG), PT Pupuk Kujang (PKC), PT Pupuk Kalimantan Timur (PKT), PT Rekayasa Industri (Rekind), hingga

${ }^{1}$ Rudhi Prasetya, Teori \& Praktik Perseroan Terbatas, Sinar Grafika, Jakarta, 2011, hlm. 75. 
PT Pupuk Indonesia Energi (PIE). Adapun PT. Semen Indonesia (Persero) Tbk. membawahi PT. Semen Padang, PT. Semen Gresik, dan PT. Semen Tonasa (Persero).

Holding company sebagai sebuah sinyal di bidang hukum Perseroan yang berkembang atas adanya reaksi terhadap kebutuhan untuk meningkatkan efisiensi ekonomi dalam kegiatan bisnis. Berkaitan dengan penjabaran perusahaan dapat terjadi suatu tatanan, bahwa sejumlah PT secara yuridis merupakan subjek hukum mandiri yang tidak memiliki hubungan satu sama lain, namun dilihat dari perspektif ekonomis seyogianya sebagai suatu kesatuan ekonomis. ${ }^{2}$

Resiko yang dihadapi sebuah holding company juga semakin beragam, salah satunya mengalami kepailitan. Sudah menjadi kebutuhan umum, meskipun telah membentuk perusahaan-perusahaan kecil, salah satu atau sebagian anak perusahaan, bahkan induk perusahaan itu sendiri dalam holding company akan melakukan pinjaman atau disebut dengan kredit. Apabila kredit tidak dapat dilunasi dan dapat ditagih karena telah jatuh tempo, tentu perusahaan tersebut dapat diajukan pailit.

Shi Jianzhong mengemukakan beberapa kemungkinan pailit dalam perusahaan holding terkait anak perusahaan yang pailit yakni, pertama, induk perusahaan dan beberapa anak perusahaan pailit; kedua, semua anak perusahaan pailit, sedangkan induk perusahaan tidak; ketiga, beberapa anak perusahaan pailit, tetapi induk perusahaan dan anak perusahaan lainnya tidak; keempat, induk perusahaan dan semua anak perusahaan pailit. $^{3}$

Holding company BUMN yang notabene merupakan perusahaan terbatas, dimasa mendatang juga berpotensi ditimpa keadaan pailit. Kepailitan merupakan suatu keadaan yang sangat dihindari bagi badan hukum yang memiliki aktivitas usaha. Kepailitan sebagaimana dijelaskan dalam Pasal 1 angka 1 Undang-Undang Nomor 37 Tahun 2004 tentang Kepailitan dan Penundaan Kewajiban Pembayaran Utang (UU KPKPU) merupakan sita umum atas semua kekayaan Debitor Pailit yang pengurusan dan pemberesannya dilakukan oleh Kurator di bawah pengawasan Hakim Pengawas sebagaimana diatur dalam Undang-Undang ini. Efek pailit tidak hanya

\footnotetext{
${ }^{2}$ Rudhi Prasetya, Kedudukan Mandiri Perseroan Terbatas disertai dengan Ulasan Menurut Undang-Undang Nomor 1 tabun 1995, Cetakan Ketiga, Citra Aditya Bakti, Bandung, 2001, hlm. 58.

3 Shi Jianzhong, Insolvency of Groups: Problem Involving Parent Companies and Their Affiliates, http://www.law.hku.hk/aiifl/wp-content/uploads/2014/07/2000_nov_shijianzhong.doc, hlm. 5 diakses pada 20 November 2018
} 
berimbas pada harta Perseroan, namun juga pada kredibilitas direksi dan/atau komisaris yang memegang jabatan pada Perseroan yang pailit. ${ }^{4}$ Meski direksi dan komisaris juga tidak selalu ditarik pertanggungjawaban secara tanggung renteng pada kekayaan pribadinya untuk melunasi utang-utang Perseroan.

Anak perusahaan holding company BUMN yang mengalami pailit akan memberikan dampak, pertama, seluruh harta kekayaan debitor anak perusahaan pailit disita untuk kepentingan kreditor, ${ }^{5}$ terlepas dari status Persero maupun bukan Persero pada anak perusahaan holding, akan tetapi anak perusahaan pailit kehilangan hak menguasai dan mengurus kekayaan sendiri. ${ }^{6}$ Semua perikatan saat putusan pernyataan pailit dijatuhkan tidak dapat dibayar dari boedel pailit, 7 dan segala penetapan pelaksanaan pengadilan sebelum kepailitan harus dihentikan, serta debitor tidak dapat dikenakan uang paksa. ${ }^{8}$ Kedua, direksi dan dewan komisaris dalam anak perusahaan pailit akan sulit menduduki pekerjaan serupa dikarenakan persyaratan untuk diangkat menjadi direksi dan dewan komisaris harus terbebas dari catatan hitam kepailitan atas perusahaan sebelumnya yang dipimpin. ${ }^{9}$ Ketiga, memengaruhi kepercayaan masyarakat khususnya pemegang saham (swasta) dalam BUMN terhadap adanya pengembangan bisnis BUMN dengan mendirikan anak perusahaan baru. Keempat, BUMN sebagai pemegang saham sedangkan swasta pemegang saham lainnya, akan kehilangan keuntungan dari sejumlah modal yang disetorkan dalam investasi. Kelima, karyawan anak perusahaan pailit secara otomatis akan mengalami Pemutusan Hubungan Kerja (PHK) apabila setelah kepailitan selesai tetapi tidak ada restrukturisasi perusahaan

4 Pasal 93 ayat (1) huruf b UU PT, "Yang dapat diangkat menjadi anggota Direksi adalah orang perseorangan yang cakap melakukan perbuatan hukum, kecuali dalam waktu 5 (lima) tahun sebelum pengangkatannya pernah: (b) menjadi anggota Direksi atau anggota Dewan Komisaris yang dinyatakan bersalah menyebabkan suatu Perseroan dinyatakan pailit." Meskipun lewat dari lima tahun sejak kepailitan Perseroan tersebut, pada praktiknya sebuah Perseroan sangat jarang dipangku oleh Direksi atau Komisaris yang pernah memiliki rekam jejak pailit pada Perseroan sebelumnya. Hal ini dikarenakan, unsur trust atau fiduciary duty pada diri direktur atau Komisaris tersebut telah hilang dari pandangan para pemegang saham saat RUPS.

${ }^{5}$ Pasal 21 jo. Pasal 1 angka 1 Undang-Undang Nomor 37 tahun 2004 tentang Kepailitan dan Penundaan Kewajiban Pembayaran Utang

6 Pasal 24 Undang-Undang Nomor 37 Tahun 2004 tentang Kepailitan dan Penundaan Kewajiban Pembayaran Utang

7 Pasal 25 Undang-Undang Nomor 37 Tahun 2004 tentang Kepailitan dan Penundaan Kewajiban Pembayaran Utang

8 Pasal 31 dan Pasal 32 Undang-Undang Nomor 37 Tahun 2004 tentang Kepailitan dan Penundaan Kewajiban Pembayaran Utang

9 Pasal 93 Undang-Undang Nomor 40 Tahun 2007 tentang Perseroan Terbatas 
hingga likuidasi. Kondisi ini berkonsekuensi pada kedudukan karyawan yang lebih tinggi daripada kreditor konkuren, yakni menjadi kreditor preferen. ${ }^{10}$

Penulis memandang penting mengetahui sejauh mana tanggung jawab holding company BUMN terhadap anak perusahaan yang mengalami kepailitan, apabila pada dasarnya akibat kepailitan berlaku pada semua jenis perseroan.

Pasal 2 ayat (5) UU KPKPU hanya mengulas sekilas tentang kepailitan BUMN, yakni dalam hal debitor merupakan perusahaan asuransi, dana pensiun, atau BUMN yang bergerak di bidang kepentingan publik, maka permohonan pailit hanya dapat diajukan oleh Menteri Keuangan. Ketentuan tersebut menunjukkan bahwa UU KPKPU tidak memberikan penjabaran lebih rinci, hal ini dikarenakan bentuk BUMN berdasarkan UU BUMN berupa Perum dan Persero.

Kepailitan BUMN Persero tidak diatur secara eksplisit di dalam UU KPKPU. Analisis terhadap UU BUMN dan UU KPKPU dapat diperoleh pemahaman, bahwa rumusan Pasal 2 ayat (5) UU KPKPU menyatakan Badan Usaha Milik Negara yang bergerak di bidang kepentingan publik adalah badan usaha yang seluruh modalnya dimiliki negara dan tidak terbagi atas saham. ${ }^{11}$ Berdasarkan Pasal 2 ayat (5) UU KPKPU tersebut dapat diketahui bahwa BUMN yang dimaksudkan ialah BUMN yang berupa Perum. Sebagaimana Pasal 1 angka 4 UU BUMN yang menentukan bahwa Perusahaan Umum yang selanjutnya disebut Perum, adalah BUMN yang seluruh modalnya dimiliki negara dan tidak terbagi atas saham, yang bertujuan untuk kemanfaatan umum berupa penyediaan barang dan/atau jasa yang bermutu tinggi dan sekaligus mengejar keuntungan berdasarkan prinsip pengelolaan perusahaan. UU BUMN menentukan pembatasan yang dimaksud BUMN adalah Perum, sehingga permohonan pailit untuk Perum hanya dapat diajukan oleh Menteri Keuangan. Artinya, saat ini belum terdapat pengaturan khusus tentang kepailitan BUMN Persero. ${ }^{12}$

10 Pasal 39 Undang-Undang Undang-Undang Nomor 37 Tahun 2004 tentang Kepailitan dan Penundaan Kewajiban Pembayaran Utang, dan Putusan Mahkamah Konstitusi Nomor 67/PUU-XI/2013. Mahkamah Konstitusi dalam Putusan Nomor 67/PUU-XI/2013 tanggal 11 September 2014 menyatakan bahwa Pasal 95 ayat (4) Undang-Undang Nomor 13 Tahun 2003 tentang Ketenagakerjaan dianggap bertentangan dengan UUD 1945 dan tidak mempunyai daya mengikat apabila tidak dimaknai "pembayaran upah pekerja/ burub yang terbutang didabulukan atas semua jenis kreditur termasuk atas tagihan kreditur separatis, tagiban hak negara, kantor lelang, dan badan umum yang dibentuk Pemerintah, sedangkan pembayaran hak-bak pekerja/ burub lainnya didabulukan atas semua tagihan termasuk tagihan hak negara, kantor lelang, dan badan umum yang dibentuk Pemerintah, kecuali tagihan dari kreditur separatis".

${ }^{11}$ Dewi Tuti Muryati, dkk, "Kajian Normatif Atas Kepailitan BUMN (Persero) dalam Kaitannya dengan Pengaturan Perseroan Terbatas”, J. DINAMIKA SOSBUD, Volume 17 Nomor 2, Juni 2015 : 29 - 40, hlm. 33.

12 Ibid. 
Pengaturan kepailitan dalam holding company BUMN juga mengalami kekosongan hukum. Padahal, sebuah holding company sama-sama memiliki resiko pailit, sehingga dimungkinkan dapat menimpa holding company BUMN. Sementara anak-anak (subsidiary) holding company BUMN tidak semuanya berbentuk BUMN Persero. Syarat diajukannya kepailitan dan dapat dijatuhkannya kondisi debitor dalam keadaan pailit justru begitu mudah. ${ }^{13}$ Status BUMN Persero sendiri tunduk pada UU PT yang dapat diajukan pailit oleh siapapun juga, kecuali BUMN Persero tersebut bergerak pada sektor tertentu, misalnya Bank, Asuransi dan perusahaan yang bergerak di bidang penghimpunan dana. ${ }^{14}$

Penelitian ini hanya akan fokus terhadap kepailitan yang dapat menjerat anak-anak perusahaan yang tergabung dalam holding company BUMN, baik anak perusahaan tersebut berstatus BUMN Persero maupun yang tidak berstatus BUMN Persero.

\section{Rumusan Masalah}

Permasalahan yang dikaji dalam penelitian ini meliputi pertama, bagaimana hubungan hukum perusahaan induk dan anak perusahaan dalam holding company BUMN? Kedua, bagaimana tanggung jawab holding company BUMN terhadap anak perusahaan yang pailit?

\section{Tujuan Penelitian}

Tujuan dari penelitian ini adalah pertama, untuk mengetahui hubungan hukum perusahaan induk dan anak perusahaan dalam Holding Company BUMN. Kedua, untuk mengetahui tanggung jawab Holding Company BUMN terhadap anak perusahaan yang pailit.

\section{Metode Penelitian}

Metode yang digunakan oleh penulis dalam penelitian ini adalah yuridisnormatif, dengan pendekatan perundang-undangan (statute approach), 15 dan

\footnotetext{
${ }^{13}$ Pasal 2 ayat (1) "Debitor mempunyai dua atau lebih Kreditor dan tidak membayar lunas sedikitnya satu utang yang telah jatuh waktu dan dapat ditagih...".

${ }^{14}$ Lihat Pasal 2 Undang-Undang Nomor 37 Tahun 2004 tentang Kepailitan dan Penundaan Kewajiban Pembayaran Utang.

15 Peter Mahmud Marzuki, Penelitian Hukum, Kencana Prenada Media Group, Jakarta, 2017, hlm. 93.
} 
berdasarkan teori-teori dan konsep hukum (conceptual approach), ${ }^{16}$ yang kemudian dikaitkan dengan permasalahan yang terjadi pada realita.

\section{Hasil Penelitian dan Pembahasan}

\section{Hubungan Hukum Perusahaan Induk dan Anak Perusahaan dalam Holding Company BUMN}

Langkah pemerintah untuk meningkatkan perekonomian di Indonesia agar tidak tertinggal dengan negara-negara berkembang lainnya ialah dengan membentuk holding company BUMN. Pengelolaan holding company BUMN ini mirip dengan holding company milik swasta. Perusahaan multinasional grup atau holding company sering memanfaatkan hubungan bisnis dengan maksud untuk mentransfer pendapatan dan pengeluaran diantara area pajak tinggi dan area pajak rendah untuk menghindari pajak secara hukum.

Jika sebuah perusahaan memiliki banyak anak perusahaan yang tergabung dalam grup, beberapa anak perusahaan menghasilkan keuntungan (profitmaking) dan yang lain menghasilkan kerugian (loss-making), kemudian hubungan bisnis dapat digunakan untuk mentransfer keuntungan beberapa anak perusahaan grup ke anak perusahaan yang mengalami kerugian. Ketika pencapaian perusahaan dan keuntungan keseluruhan grup tidak berubah (stagnan), keseluruhan pajak grup dapat dikurangi, dan pajak dapat dihindari secara legal. ${ }^{17}$

Holding company adalah sebuah induk perusahaan dengan tujuan untuk memiliki saham dalam satu atau lebih perusahaan lain dan/atau menguasai, mengelola, mengatur satu atau lebih perusahaan lain tersebut. ${ }^{18}$ Munir Fuady berpendapat bahwa perusahaan induk yakni perusahaan yang bertujuan memiliki saham satu atau lebih di perusahaan lain dan/atau mengatur satu atau lebih perusahaan lain tersebut, akan tetapi kenyataannya perusahaan tersebut bergerak dalam bidang bisnis yang berbeda. ${ }^{19} \mathrm{Hal}$ ini disebut sebagai holding secara vertikal. Sedangkan apabila bisnisnya dalam lini yang sejenis disebut holding secara horizontal.

${ }^{16}$ Ibid., hlm. 137.

${ }^{17}$ Shi Jianzhong, Op.Cit., hlm. 3.

18 Sri Rejeki Hartono, Kapita Selekta Hukum Perusahaan, Mandar Maju, Bandung, 2000, hlm. 89.

${ }_{19}$ Munir Fuady, Hukum Perusahaan Dalam Paradigma Hukum Bisnis, PT. Citra Aditya Bakti, Bandung, 1999, hlm 19. 
Holding company merupakan sebuah badan usaha dengan tujuan untuk menguasai sebagian besar saham dari badan usaha yang akan dipengaruhinya. ${ }^{20}$

Menurut Black's Law Dictionary, holding company adalah a super-corporation which owns or at least controls such a dominant interest in one or more other corporations that it is enabled to dictate their policies through voting power; a corporation organized to hold the stock of other corporations; any company, incorporated or unincorporated, which is in a position to control or materially influence the management of one or more other companies by virtue, in part at least, of its ownership or securities in the other company or companies. ${ }^{21}$

Holding company sebagai suatu gabungan atau susunan dari berbagai Perseroan yang secara yuridis independen, berkaitan satu dengan yang lain secara erat membentuk kesatuan ekonomi yang tunduk pada suatu pimpinan yaitu suatu perusahaan induk sebagai pimpinan sentral. ${ }^{22}$ Hampir sama halnya dengan pengertian sebuah induk perusahaan, PT, atau persekutuan terbatas yang pemegang sahamnya memiliki hak suara (voting) dalam Rapat Umum Pemegang Saham (RUPS) pada perusahaan lain untuk mengontrol kebijakan dan manajemen didalamnya. Perusahaan induk tidak hanya memiliki beberapa operasional atau aktivitas bisnis sendiri, melainkan ia memiliki satu atau lebih aset perusahaan. ${ }^{23}$

Berdasarkan sistem civil law yang dianut Indonesia, PT merupakan entitas hukum (legal entity) tersendiri sebagai subjek hukum yang dibebani hak dan kewajiban. Meskipun tidak ada pengaturan khusus mengenai perusahaan holding company di dalam UU PT, pada praktiknya anak-anak perusahaan didirikan dengan status PT. Sehingga memiliki kedudukan sebagai entitas hukum yang independen dan mandiri sebagai subjek hukum. Anak-anak perusahaan dapat berkedudukan sebagai pihak yang memiliki harta kekayaan sendiri, melakukan perbuatan hukum secara perdata serta dapat menggugat dan digugat di hadapan pengadilan. Hans Kelsen menentukan kriteria entitas hukum yang meliputi, The being or artificial person; Conduct; Legal capacity; Subjective rights; Obligations The will; and Juridical personality. ${ }^{24}$

\footnotetext{
${ }^{20}$ Komaruddin, Ekonomi Perusahaan dan Manajeman, Alumni, Bandung, 2009, hlm. 161.

${ }^{21}$ Black Law's Dictionary, 4th edition, West Publishing, 1968, hlm. 865.

22 Emmy Pangaribuan Simanjuntak, Perusahaan Kelompok, Seksi Hukum Dagang Fakultas Hukum Universitas Gajah Mada, Yogyakarta, 1996, hlm. 1.

23 Amy Fontinelle, Holding Company, Holding Company https://www.investopedia.com/terms/h/ holdingcompany.asp\#ixzz5TgCxsSOA diakses tanggal 11 Oktober 2018.

${ }^{24}$ Elvia A.Q. Adriano, "The Natural Person, Legal Entity or Juridical Person and Juridical Personality", Penn State Journal of Law \& International Affairs, Vol. 4, Issue 1 Seventeenth Biennal Meeting of The International Academy of Commercial and Consumer Law, 2015, 364-391, hlm. 374-375.
} 
Manakala perusahaan mendirikan anak perusahaan, maka penyertaan modal kepada anak perusahaan tersebut berasal dari kekayaan perusahaan, bukan dari pemegang modal dari perusahaan induk. Akibatnya, adanya perbedaan pertanggungjawaban antara perusahaan induk dan anak perusahaan. Pertanggungjawaban yang dimaksud ialah pihak mana dari perusahaan tersebut mempertanggungjawabkan segala kegiatan usahanya. ${ }^{25}$ Hubungan hukum yang muncul yaitu hubungan antara pemegang saham dengan perusahaan. Keterlibatan induk perusahaan bertanggungjawab terhadap kerugian anak perusahaan apabila terdapat dominasi induk perusahaan terhadap anak perusahaan. ${ }^{26}$

Induk perusahaan dan anak perusahaan sama-sama memiliki entitas hukum, sehingga berlaku pula hak dan kewajiban yang terbatas dalam lapangan harta kekayaan (limited liability). Prinsip limited liability mengenai harta kekayaan terpisah, bermakna bahwa harta kekayaan pemegang saham (share holders) dengan harta kekayaan badan hukum benar-benar terpisah. ${ }^{27}$ Apabila badan hukum memiliki utang, maka pemegang saham tidak dapat dimintai pertanggungjawaban untuk pembayaran utang badan hukum tersebut, demikian sebaliknya. Selain itu, kerugian yang ditanggung oleh pemegang saham sebatas modal yang disetorkan ke dalam Perseroan.

Holding company BUMN memiliki keistimewaan-keistimewaan sebagai anak perusahaan holding yakni statusnya dipersamakan dengan BUMN itu sendiri. Maksud dipersamakan dalam hal ini yaitu berupa keistimewaan menjalankan dan mengembangkan bisnis tertentu yang berhubungan dengan hajat hidup orang banyak atau sumber-sumber daya alam yang penting bagi negara. Meskipun perusahaan induk sebagai BUMN dan anak perusahaan belum tentu berstatus BUMN. ${ }^{28}$ Akan tetapi, status badan hukum anak perusahaan yang berstatus bukan

\footnotetext{
${ }^{25}$ Julio Thimotius Kapitan Smaud Natun, "Status Kepemilikan Anak Perusahaan BUMN", Mimbar Keadilan, Volume 12 Nomor 1, Februari 2019-Juli 2019, hlm. 6.

${ }^{26}$ Termasuk didalamnya perbuatan melawan hukum atau wanprestasi dan adanya unsur kerugian dari pihak lain. Sehingga pertanggung jawaban induk perusahaan terhadap anak perusahaan dapat berupa tanggung jawab pribadi, tanggung renteng dan tanggung jawab sampai batas-batas tertentu. Ibid.

${ }_{27}$ Putu Edgar Tanaya dan Kadek Agus Sudiarawan, "Akibat Hukum Kepailitan Badan Usaha Milik Negara Pasca berlakunya Undang-Undang Nomor 17 tahun 2003 tentang Keuangan Negara", Jurnal Komunikasi Hukum, Vol 3, No. 1, 2017, 117-126, hlm. 5.

28 Nanda Narendra Putra, Isu Monopoli dan Kepailitan di Tengah Holding BUMN Tambang, http://www.hukumonline.com/berita/baca/lt5a376d99c3672/isu-monopoli-dan kepailitan-di-tengah-holding-
} 
Persero, baik secara organisatoris dan tata cara pendiriannya tetap tunduk pada UU PT.

BUMN merupakan badan usaha yang seluruh atau sebagian besar modalnya dimiliki oleh negara melalui penyertaan secara langsung dari kekayaan negara yang dipisahkan. ${ }^{29}$ BUMN dibagi menjadi 2 (dua) jenis yakni Perusahaan Perseroan (Persero) dan Perusahaan Umum (Perum). Persero juga dibagi dua jenis yakni Persero tertutup dan Persero terbuka yang terjun di lantai bursa dengan modal dan jumlah pemegang saham harus memenuhi kriteria tertentu atau Persero yang melakukan penawaran umum sesuai dengan peraturan perundang-undangan di bidang pasar modal. ${ }^{30}$

Perbedaan antara Persero dengan Perum terletak pada penyertaan modal negara dan tujuan dibentuknya BUMN tersebut. Penyertaan modal pada Persero terbagi dalam saham, yang secara keseluruhan atau minimal 51\% sahamnya dimiliki oleh Negara Republik Indonesia dan bertujuan untuk mengejar keuntungan sebesar-besarnya layaknya pendirian PT pada umumnya. Sedangkan pada Perum, keseluruhan modal dalam BUMN tersebut dimiliki Negara Republik Indonesia dan tidak terbagi atas saham. Tujuan pendirian Perum BUMN demi kemanfaatan umum yang berupa penyediaan barang dan jasa sekaligus mengejar keuntungan berdasarkan prinsip pengelolaan perusahaan. ${ }^{31}$

Pasal 4 ayat (1) UU BUMN mengatur, bahwa modal Persero merupakan dan berasal dari kekayaan negara yang dipisahkan, serta penyertaan modal negara dalam rangka pendirian dan penyertaan pada BUMN bersumber dari APBN. ${ }^{32}$ BUMN Persero hakikatnya merupakan korporasi, yaitu sebuah badan usaha berbadan hukum yang bertujuan mencari keuntungan. Memahami makna dan dampak badan hukum yang demikian ini, maka diperoleh pengertian yang utuh tentang Persero. Badan hukum ialah suatu badan yang berhak melakukan suatu

\footnotetext{
bumn-tambang; vide Pasal 2A ayat (7) PP Nomor 72 Tahun 2016 tentang Perubahan Atas PP Nomor 44 Tahun 2005 tentang Tata Cara Penyertaan dan Penatausahaan Modal Negara pada BUMN

${ }^{29}$ Pasal 1 Angka 1 Undang-Undang Nomor 19 Tahun 2003 tentang Badan Usaha Milik Negara

30 Pasal 1 Angka 2 Undang-Undang Nomor 19 Tahun 2003 tentang Badan Usaha Milik Negara Negara

${ }^{31}$ Lihat Pasal 1 angka 2 jo. Angka 3 Undang-Undang Nomor 19 Tahun 2003 tentang Badan Usaha Milik

32 Rizal Widia Priangga dan Yudho Taruno Muryanto, “Analisis Yuridis Sita Umum Aset Badan Usaha Milik Negara Terhadap Undang-Undang Nomor 1 Tahun 2004 tentang Perbendaharaan Negara”, Jurnal Hukum, Vol. V, No.1, 2009, 124-130, hlm. 3.
} 
perbuatan seperti manusia, memiliki kekayaan sendiri, serta digugat dan menggugat di depan Pengadilan. 33

Pasal 11 UU BUMN menegaskan bahwa terhadap Persero diberlakukan prinsip-prinsip dan ketentuan sebagaimana terdapat dalam UU PT. Berdasarkan UU PT (meski tidak ditentukan secara eksplisit) tetap dapat dimengerti bahwa anak perusahaan dari suatu PT sebagai badan hukum independen. ${ }^{34}$ Prinsip sebagai badan hukum berbentuk PT merupakan prinsip dasar sebuah entitas hukum yang tidak dapat disimpangi.

Pengertian anak perusahaan BUMN Persero diatur dalam Peraturan Menteri Negara BUMN No. PER-03/MBU/2012 Tahun 2012 tentang Pedoman Pengangkatan Anggota Direksi dan Anggota Dewan Komisaris Anak Perusahaan Badan Usaha Milik Negara (Permen BUMN No. 3/2012). Pasal 1 angka 2 Permen BUMN No. 3/2012 menjelaskan, bahwa Anak Perusahaan BUMN adalah Perseroan terbatas yang sebagian besar sahamnya dimiliki oleh BUMN atau Perseroan terbatas yang dikendalikan oleh BUMN. Menurut pasal tersebut, dapat dimaknai bahwa BUMN sebagai induk perusahaan memiliki porsi kewenangan lebih besar terhadap anak perusahaannya terkait dengan pengurusan dan pengelolaan perusahaan.

Menteri yang menyelenggarakan urusan pemerintahan dibidang BUMN hanya berwenang mengangkat dan memberhentikan Direksi dan Komisaris BUMN Persero yang seluruh sahamnya dimiliki oleh negara. Menteri tidak berwenang terhadap anak perusahaan BUMN, karena selain bukan berstatus sebagai BUMN, saham anak perusahaan BUMN tidak dimiliki oleh negara secara langsung. ${ }^{35}$ Pasal 2 ayat (2) Permen BUMN No. 3/2012 juga menentukan, bahwa Pengangkatan anggota Direksi dan anggota Dewan Komisaris Anak Perusahaan dilakukan oleh RUPS Anak Perusahaan yang bersangkutan melalui proses pencalonan berdasarkan pedoman yang diatur dalam Peraturan Menteri ini. Ditegaskan pula dalam Pasal 19 Permen BUMN No. 3/2012, bahwa Pemberhentian anggota Direksi dan/atau Dewan

\footnotetext{
33 Chaidir Ali dalam Ridwan Khairandy, "Konsepsi Kekayaan Negara Dipisahkan dalam Perusahaan Perseroan”, Jurnal Hukum Bisnis, Vol. 26, No.1, 2007, hlm. 33.

34 Inda Rahadiyan, "Kedudukan BUMN Persero Sebagai Separate Legal Entity dalam Kaitannya dengan Pemisahan Keuangan Negara dalam Permodalan BUMN”, Jurnal Hukum Ius Quia Iustum, Vol. 20, No.4, 2013, 624640, hlm. 631-632.

35 Ilman Hadi, Status Hukum Anak Perusahaan BUMN, https://www.hukumonline.com/klinik /detail/lt50629054c7269/status-hukum-anak-perusahaan-bumn, diakses tanggal 10 September 2018..
} 
Komisaris Anak Perusahaan, sepenuhnya merupakan kewenangan Direksi BUMN melalui RUPS Anak Perusahaan yang bersangkutan sesuai dengan ketentuan peraturan perundang-undangan. Menteri BUMN hanya memiliki kewenangan terhadap BUMN saja, sedangkan anak perusahaan BUMN bersifat mandiri terhadap pengangkatan anggota Direksi dan anggota Dewan Komisaris. ${ }^{36}$

Hal ini menunjukkan bahwa seyogianya anak perusahaan BUMN berkedudukan dibawah pengaruh besar induk perusahaannya, yakni BUMN itu sendiri. Karena, meski pengangkatan Direksi dan Dewan Komisaris anak perusahaan melalui RUPS anak perusahaan, pengendalian baik langsung maupun tidak langsung tetap didominasi oleh holding BUMN. Ditambah lagi pemberhentian Direksi dan Dewan Komisaris menjadi kewenangan Direksi BUMN melalui Rapat Umum Pemegang Saham (RUPS) anak perusahaan.

UU PT dan peraturan perundang-undangan yang lain masih memberikan pengakuan terhadap status badan hukum sendiri dan anak perusahaan sebagai subjek hukum mandiri. Hal demikian berimplikasi pada status induk dan anak perusahaan yang masing-masing tetap merupakan subjek hukum mandiri meskipun saling terkait sebagai satu kesatuan ekonomi. ${ }^{37}$ Bentuk pengakuan yuridis terhadap anak perusahaan sebagai subjek hukum mandiri menunjukan bahwa kerangka pengaturan terkait antara induk dan anak perusahaan masih menggunakan pendekatan Perseroan tunggal, meskipun anak perusahaan menjadi bagian dari kesatuan ekonomi bagi induknya. ${ }^{38}$ UU PT melegitimasi Perseroan untuk memperoleh atau memiliki saham pada Perseroan lain melalui sejumlah rancangan pengaturan yang mengizinkan suatu Perseroan untuk mendirikan Perseroan lain, melakukan pengambil alihan (akuisisi) saham Perseroan lain serta melakukan pemisahan diri menjadi badan hukum tersendiri (spin off). ${ }^{39}$

Pola hukum tersebut dalam praktik bisnis dewasa ini tentu dapat memberikan celah hukum induk perusahaan untuk mengendalikan dan mendominasi pengurusan anak perusahaan. Dominasi induk terhadap anak perusahaan menyebabkan orientasi kepentingan ekonomi anak perusahaan

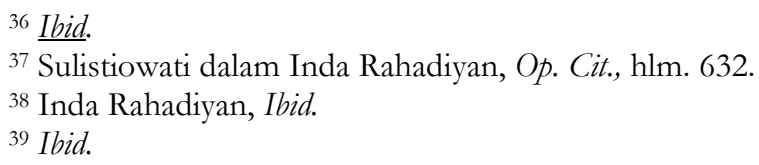


seutuhnya ditujukan untuk menunjang kepentingan holding company. ${ }^{40}$ Menurut penulis, tidak dapat dipungkiri jika eksistensi anak perusahaan dalam sebuah holding company memang ditujukan untuk memperkuat kedudukan holding itu sendiri, khususnya dari segi keuntungan atau kepentingan ekonomi.

Legitimasi UU PT terhadap kepemilikan induk perusahaan terhadap saham anak perusahaan memberikan label dimasukannya konsep controlling oleh induk perusahaan kepada anak perusahaan ke dalam lingkup hukum Perseroan. Konsepsi tersebut telah rnenimbulkan munculnya kontradiksi aspek yuridis dengan aspek realitas hukum bisnis mengenai keterkaitan antara induk dengan anak perusahaan. Sulistiowati menyatakan, bahwa konsepsi pengendalian oleh Perseroan terhadap Perseroan lain seharusnya tidak berada dalam ranah hukum Perseroan, karena pengendalian oleh suatu Perseroan terhadap Perseroan lainnya mengakibatkan lahirnya hubungan subordinasi diantara badan hukum yang sejatinya bersifat mandiri. ${ }^{41}$ UU PT justru telah mengambil konsepsi pengendalian tersebut. Kondisi demikian ini yang sekiranya terjadi terhadap keterkaitan antara BUMN dengan anak perusahaan, sehingga BUMN sebagai induk perusahaan memiliki kebebasan turut melakukan campur tangan dalam pengelolaan anakanak perusahaannya. ${ }^{42}$

Sebuah kondisi yang bertentangan dengan prinsip kemandirian anak perusahaan yang sejatinya merupakan separate legal entity. Terhadap konteks luas, konsepsi kedudukan anak perusahaan BUMN menjadi sangat penting khususnya saat terkait dengan perbuatan-perbuatan bisnis (corporate action) tertentu, baik dilakukan oleh dan/atau menyangkut anak perusahaan BUMN. ${ }^{43}$

\section{Tanggung Jawab Holding Company BUMN terhadap Anak Perusahaan yang Pailit}

Pasal 40 ayat (2) Kitab Undang-Undang Hukum Dagang (KUHD) menyatakan, bahwa pemegang saham tidak bertanggung jawab lebih daripada jumlah penuh saham-saham itu. Prinsip yang sama juga diberlakukan Pasal 3 ayat (1) UU PT

\footnotetext{
${ }^{40}$ Sulistiowati, Tanggung Jawab Hukum Pada Perusahaan Grup di Indonesia, Erlangga, Jakarta, 2013, hlm. 5-6.

${ }^{41}$ Sulistiowati dalam Inda Rahadiyan, Op. Cit., hlm. 632-633.

42 Inda Rahadiyan, Ibid., hlm. 633.

${ }^{43}$ Ibid.
} 
yang menyatakan dengan tegas, bahwa Perseroan Terbatas merupakan badan hukum dan tanggung jawabnya hanya sebatas saham-saham yang telah diambil oleh pemegang saham.

Holding company bertanggung jawab atas anak perusahaan sebatas kewenangan yang diberikan kepadanya, baik dalam hal management dan kebijakan perusahaan yang lain. Akan tetapi, apabila perusahaan anak tersebut sebagai perusahaan dalam bentuk PT yang mandiri maka induk perusahaan tidak dapat dipertanggungjawabkan secara yuridis. Pemegang saham juga hanya bertanggung jawab sebatas nilai modal saham yang disetorkan di dalam perusahaan tersebut. ${ }^{44}$

Prinsip piercing the corporate veil mengubah konsep pertanggungjawaban ini, bahwa tanggung jawab pemegang saham menjadi tidak terbatas, apabila pemegang saham ikut terlibat dalam hal yang dapat mengakibatkan kerugian pada Perseroan. Seperti yang tertuang dalam Pasal 3 ayat (1) UU PT, Pemegang saham Perseroan tidak bertanggung jawab secara pribadi atas perikatan yang dibuat atas nama Perseroan dan tidak bertanggung jawab atas kerugian Perseroan melebihi saham yang dimiliki. Selanjutnya, ditegaskan pada ayat (2) yang menyatakan ketentuan sebagaimana dimaksud pada ayat (1) tidak berlaku apabila:

a. persyaratan Perseroan sebagai badan hukum belum atau tidak terpenuhi,

b. pemegang saham yang bersangkutan baik langsung maupun tidak langsung dengan itikad buruk memanfaatkan Perseroan untuk kepentingan pribadi

c. pemegang saham yang bersangkutan terlibat dalam perbuatan melawan hukum yang dilakukan oleh Perseroan; atau

d. pemegang saham yang bersangkutan baik langsung maupun tidak langsung secara melawan hukum menggunakan kekayaan Perseroan, yang mengakibatkan kekayaan Perseroan menjadi tidak cukup untuk melunasi utang Perseroan.

Prinsip piercing the corporate veil mengandung 3 unsur yang harus dibuktikan oleh penggugat dalam menerapkan prinsip ini. Unsur tersebut yakni: (1) kontrol dan dominasi, (2) tujuan atau penggunaan yang tidak patut, dan (3) menghasilkan kerugian. ${ }^{45}$ Selain dapat menjerat pemegang saham, prinsip ini juga dapat menjerat Direksi (Pasal 97 UUPT) dan Dewan Komisaris (Pasal 114 ayat (2) UUPT).

\footnotetext{
44 Pasal 3 ayat (1) Undang-Undang Nomor 40 Tahun 2007 tentang Perseroan Terbatas, Lihat juga P Jhon F Sipayung, "Tinjauan Yuridis Holdingisasi Bumn Dalam Rangka Peningkatan Kinerja Menurut Perspektif Hukum Perusahaan”, Jurnal Hukum Ekonomi, Vol. I, No. 1, 1-8, 2013, hlm. 8.

45 Moris v Department of taxation\&Fin dan Belvedere Condominium Owner v R.E Roark Cos dalam Harshit Saxena, Lifting of Corporate Veil, http://ssrn.com/abstract=1725433, hlm.15, diakses pada 26 Mei 2019.
} 
Induk perusahan atau holding dalam tradisi sistem hukum common law tidak bertanggung jawab pada utang anak-anak perusahaannya, namun ada beberapa resiko tanggung jawab adanya hubungan yang terdiri dari:46

1. Contractual obligation (suretyship, guarantee, "hard" letter of comfort).

2. Unpaid or repaid capital contributions.

3. Intercompany agreements, any net losses.

4. Setting aside transactions (repayments of shareholder loans within one year before the insolvency petition).

5. Tort (causing intentional damage to the company contrary to public policy).

6. Where companies do not provide limited liability (general partnership and a nontrading partnership).

Pemegang saham dapat ditarik pertanggungjawaban secara pribadi apabila terbukti terlibat menyebabkan Perseroan tersebut gagal dalam memenuhi pelunasan hutang yang jatuh tempo.

Berkenaan dengan kepailitan dalam holding company, perusahaan induk sendiri dilindungi dari kerugian. Jika salah satu anak perusahaan bangkrut atau pailit, perusahaan induk mengalami kerugian modal dan penurunan kekayaan bersih, tetapi debitur dan kreditur perusahaan yang pailit tidak dapat menuntut bahkan melakukan penagihan perusahaan induk untuk mendapatkan imbalan atau ganti kerugian. ${ }^{47}$ Sebagaimana esensi hukum kepailitan bahwa, "...the realization of the assets of the debtor for onward distribution among competing creditors and claimholders. The bankruptcy system is, also utilized in managing the wide spectrum of the deleterious effects of business failure especially with the prospect of imminent failure of the defaulting persons or entity". ${ }^{4}$

Adanya prinsip separate legal entity yang berarti bahwa antara induk perusahaan dan anak perusahaan masing-masing berdiri secara mandiri sebagai badan hukum. Hal ini dikarenakan, masing-masing anak perusahaan maupun holding company merupakan badan hukum yang terpisah. Apabila terdapat tuntutan hukum terhadap suatu perusahaan, maka tuntutan itu tidak dapat

46 Practical Law, Parent Entity Liability in Insolvency, https://uk.practicallaw.thomsonreuters.com/ 85667187 ?transition Type $=$ Default $\&$ contextData $=($ sc.Default $) \&$ firstPage $=$ true $\&$ comp $=$ pluk $\& b h c p=1, \quad$ diakses pada 15 Desember 2018.

47 Amy Fontinelle, Op. Cit.

48 Adegbemi Babatunde Onakoya and Ayooluwa Eunice Olotu, "Bankcruptcy and Insolvency : An Exploration of Relevant Theories", International Journal of Economics and Financial Issue, Vol. 7, Issue 3, 2017, 706712, hlm. 709. 
ditujukan kepada anak perusahaan yang lain yang tergabung dalam holding atau terhadap holding company-nya, demikian pula sebaliknya. ${ }^{49}$

Syarat perusahaan dapat dipailitkan diatur dalam Pasal 2 ayat (1) UU KPKPU, bahwa debitor yang mempunyai dua atau lebih Kreditor dan tidak membayar lunas sedikitnya satu utang yang telah jatuh waktu dan dapat ditagih, dinyatakan pailit dengan putusan Pengadilan, baik atas permohonannya sendiri maupun atas permohonan satu atau lebih kreditornya.

Debitor yang terbukti memenuhi syarat di atas dapat dinyatakan pailit, baik debitur perorangan maupun badan hukum. Pihak yang dapat dinyatakan pailit salah satunya holding company yakni UU KPKPU tidak memberikan syarat khusus bahwa permohonan kepailitan terhadap holding company dan anak-anak perusahaannya harus diajukan dalam satu dokumen yang sama. Artinya, selain dapat diajukan dalam satu permohonan, permohonan-permohonan ini juga dapat diajukan secara terpisah sebagai dua permohonan..$^{50}$ Maknanya ialah, pemohon diberikan keleluasaan dalam mengajukan kepailitan terhadap suatu holding company berikut dengan anak-anak perusahaannya.

Penjelasan di atas menunjukkan bahwa pemisahan relasi secara yuridis antara induk perusahaan dengan anak perusahaan terjadi secara organisatoris. Berbeda halnya apabila menyangkut keberadaan pemegang saham. Prinsip piercing the corporate veil memungkinkan pemegang saham anak perusahaan dapat ditarik untuk turut bertanggung jawab. Perlu ditegaskan bahwa pemegang saham dalam anak perusahaan BUMN bukanlah negara, melainkan BUMN itu sendiri. RUPS pemegang saham dalam anak perusahaan BUMN yakni direksi BUMN. Apabila pertanggungjawaban menjangkau pemegang saham dalam persoalan kepailitan anak perusahaan holding BUMN, maka yang akan dilibatkan adalah direksi BUMN selaku pemegang saham anak perusahaan.

Konstruksi Pasal 4 dan Pasal 11 UU PT yang dikaitkan dengan tanggung jawab direksi menurut Pasal 92 UU PT, menegaskan bahwa dalam menjalankan perusahaan untuk kepentingan Perseroan dan sesuai dengan maksud dan tujuan

${ }^{49}$ Ahmad Yani \& Gunawan Widjaja, Seri Hukum Bisnis Perseroan Terbatas, Raja Grafindo Persada, Jakarta, 1999, hlm. 156.

${ }^{50}$ Imran Nating, Hukum Kepailitan, Pustaka Utama Grafiti, Jakarta, 2002, hlm. 42. 
Perseroan, direksi berwenang menjalankan pengurusan sesuai dengan kebijakan yang dipandang tepat, dalam batas yang ditentukan undang-undang dan anggaran dasar. Demikian halnya kewenangan direksi dalam BUMN Persero juga tunduk pada peraturan perundang-undangan yang mengatur PT dan anggaran dasarnya. ${ }^{51}$ Dewi Tuti Muryati menyatakan bahwa:

Kepailitan Persero yang diakibatkan oleh kesalahan atau kelalaian direksi, sementara harta pailit tidak cukup untuk membayar seluruh kewajiban Perseroan, maka setiap anggota direksi secara tanggung renteng bertanggung jawab atas seluruh kewajiban, apabila anggota direksi dapat membuktikan bahwa kepailitan tersebut bukan karena kesalahan atau kelalaiannya, dan telah melakukan pengurusan dengan iktikad baik dan penuh tanggung jawab untuk kepentingan Perseroan maka anggota direksi tersebut tidak bertanggung jawab atas kepailitan Perseroan. ${ }^{52}$

Begitupula apabila anak-anak perusahaan mengalami kepailitan, Direktur BUMN harus mampu membuktikan bahwa pengaruh dan keputusannya dalam pengelolaan anak-anak perusahaannya tersebut telah didasari oleh pertimbangan yang matang dan bukan akibat kelalaiannya. Direktur BUMN dapat terbebas dari tanggung jawab terhadap kepailitan anak perusahaan apabila dapat membuktikan hal tersebut.

Induk perusahaan tetap dapat diminta pertanggungjawaban apabila terbukti bahwa:53 pertama, ada keterlibatan induk perusahaan dalam menentukan manajemen perusahaan, keuangan, keputusan bisnis yang menyebabkan kerugian Perseroan, misalnya dalam mengambil kredit dari perbankan ikut menentukan jumlah, peruntukan dan penggunaannya sehingga Perseroan mengalami kerugian hingga pailit. Kedua, tindakan yang dilakukan oleh anak perusahaan untuk kepentingan induk perusahaan. Ketiga, induk perusahaan secara tidak layak mengacuhkan masalah kecukupan finansial dari anak perusahaan. ${ }^{54}$ Sebagaimana juga telah ditegaskan dalam Pasal 3 ayat (2) huruf (b), huruf (c), dan huruf (d) UU PT, bahwa dalam keadaan tertentu pemegang saham dapat dimintai pertanggungjawaban hingga harta pribadi.

\footnotetext{
${ }^{51}$ Dewi Tuti Muryati, dkk, Op. Cit., hlm. 36-37.

${ }^{52}$ Ibid.

${ }^{53}$ Rita Diah Widawati, “Tanggung Jawab Induk Perusahaan Terhadap Perikatan Yang Dilakukakan Oleh Anak Perusahaan”, Tesis, Medan, Magister Kenotariatan USU, 2009, hlm. 117-118

${ }^{54}$ Ibid.
} 
Induk perusahaan yang diwakili oleh direksi BUMN merupakan pemegang saham terbesar dalam anak perusahannya. Pada umumnya, pemegang saham terbesar menjadi pemegang saham pengendali dalam suatu anak perusahaan. Sehingga, wajar apabila induk perusahaan yang dalam hal ini BUMN turut mengendalikan manajemen anak perusahaannya. Apabila keputusan-keputusan rapat direksi dan komisaris anak perusahaan banyak dipengaruhi dan dikendalikan oleh holding BUMN yang justru menimbulkan kepailitan, maka holding BUMN sebagai pemegang saham anak perusahaan yang diwakili direksi BUMN dapat dipertanggungjawabkan.

Pasal 19 ayat (3) Peraturan Menteri Negara Badan Usaha Milik Negara Nomor: Per- 09 /Mbu/2012 Tentang Perubahan Atas Peraturan Menteri Negara Badan Usaha Milik Negara Nomor Per-01/Mbu/2011 Tentang Penerapan Tata Kelola Perusahaan Yang Baik (Good Corporate Governance), menegaskan bahwa Direksi BUMN harus menyampaikan informasi mengenai identitas, pekerjaanpekerjaan utamanya, jabatan Dewan Komisaris di anak perusahaan/perusahaan patungan dan/atau perusahaan lain, termasuk rapat-rapat yang dilakukan dalam satu tahun buku (rapat internal maupun rapat gabungan dengan Dewan Komisaris/Dewan Pengawas), serta gaji, fasilitas, dan/atau tunjangan lain yang diterima dari BUMN yang bersangkutan dan anak perusahaan/perusahaan patungan BUMN yang bersangkutan, untuk dimuat dalam Laporan Tahunan BUMN.

Hal ini menunjukkan bahwa meskipun menganut separate legal entity, akan tetapi karena kekhususannya sebagai BUMN, anak-anak perusahaan BUMN tetap masuk dalam laporan tahunan atau laporan direksi BUMN. Termasuk apabila terjadi kepailitan, holding BUMN akan membawa isu tersebut ke meja Direksi bersama dengan RUPS dalam hal 100\% modal BUMN dimiliki negara, dan Menteri BUMN bertindak sebagai RUPS itu sendiri. Secara mutatis mutandis, Direksi membawa persoalan ini kehadapan Menteri BUMN. Namun, apabila saham BUMN yang dimiliki oleh negara hanya sebagian saja, maka Menteri BUMN yang bertindak selaku pemegang saham dari negara beserta pemegang saham lainnya diperlukan untuk hadir dalam RUPS. 
Induk perusahaan BUMN biasanya justru diminta oleh kreditor untuk menjadi penanggung (guarantor) anak perusahaan. Bahkan anak perusahaan juga dimungkinkan untuk diminta menjadi guarantor terhadap utang holding company atau utang dari anak perusahaan yang lain. Guarantee seperti itu tentu bertentangan dengan kepentingan bisnis dari guarantor dengan kemungkinan risiko yang tinggi pula. ${ }^{55}$ Mempersilahkan perusahaan induk bertanggung jawab terhadap utangutang kepailitan anak perusahaannya merupakan sebuah cara yang membantu. Akan tetapi, hal tersebut merusak prinsip limited liability atau prinsip tanggung jawab terbatas pemegang saham dari utang-utang perusahaan, dan banyak faktor yang harus dipertimbangkan. ${ }^{56}$

Shi jianzhong, menawarkan sebuah upaya penyelamatan perusahaan yang pailit dengan induk perusahaan melalui beberapa metode, meliputi:57 1. jika perusahaan induk dan anak perusahaan sepenuhnya independen dalam operasinya, hak kreditor perusahaan induk tidak dirusak oleh bisnis anak perusahaan, maka independensi perusahaan induk dan anak perusahaan dapat dikonfirmasikan, dan kreditor dari perusahaan induk dan anak perusahaan akan menerapkan hak kreditor mereka berdasarkan pada properti perusahaan induk atau anak perusahaan masing-masing. (Henderson v. Rounds dan Porter Lumber Co., 99 F. Supp. 376 (W.D.Ark 1951). 2. jika properti dan bisnis tidak dipisahkan antara perusahaan induk dan anak perusahaan, atau bahkan dicampur, maka anak perusahaan sebenarnya adalah alat perusahaan induk. Dalam hal ini, kreditor perusahaan induk dan perusahaan anak dapat membagi properti perusahaan induk dan perusahaan anak secara merata. Jika kreditor dari perusahaan induk atau kreditor dari anak perusahaan dikompensasi lebih disukai, akan ada ketidakadilan. (Stone v. Eacho, 128 F. 2d 284 (4th Cir. 1942). 3. jika anak perusahaan bangkrut, bahkan hutang anak perusahaan terjadi sebelum perusahaan induk mengendalikan bisnisnya, para kreditor anak perusahaan masih dapat meminta kompensasi dari perusahaan induk. Tetapi batasnya adalah bahwa hak-hak kreditor dari perusahaan induk tidak boleh rusak.

${ }^{55}$ Munir Fuady, Op. Cit., hlm. 107.

${ }^{56}$ Shi Jianzhong, Op. Cit., hlm. 8-10.

${ }^{57}$ Ibid., hlm. 8. 
Anak perusahan BUMN merupakan aset BUMN termasuk dalam aset negara meski tidak secara langsung. Demi kekuatan ekonomi nasional, maka sudah sewajarnya holding BUMN sebagai induk perusahaan mengulurkan tangan demi penyelamatan anak perusahaan yang pailit tersebut, terlepas dari holding BUMN turut serta mengakibatkan kepailitan karena dominasi dalam rapat serta pengelolaan keuangan anak perusahaan atau tidak. Upaya yang dapat dilakukan holding BUMN untuk menyelamatkan anak perusahaan pailit antara lain sebagai berikut: 1. melakukan restrukturisasi perusahaan secara menyeluruh. Dikarenakan bargaining position holding BUMN lebih kuat selaku pemegang saham di dalam anak perusahaan, terlebih apabila turut serta terhadap manajemen keuangan dan mengendalikan suara dalam rapat direksi perusahaan, sudah sewajarnya bagi holding BUMN untuk mengambil langkah kebijakan berupa restrukturisasi. Termasuk di dalamnya melakukan akuisisi. 2. pihak holding BUMN dapat mengajukan kompensasi sub-ordinat. Sebuah prosedur pengalokasian properti perusahaan yang pailit, permintaan kompensasi perusahaan terkait (termasuk perusahaan induk, anak perusahaan dan afiliasinya) dari debitur harus ditunda sampai kreditor lainnya diberi kompensasi, dan kemudian sisa properti digunakan untuk membayar utang perusahaan terkait. ${ }^{58}$ 3. mengajukan Penundaan Kewajiban Pembayaran Utang (PKPU), hal ini dalam rangka mencari investor baru dari relasi holding BUMN agar memasukkan dana segar dalam anak perusahaan yang jatuh pailit tersebut. Sehingga, selain utang-utang dapat dibayarkan secara lunas kepada para kreditor, anak perusahaan dapat melangsungkan kegiatan usahanya lagi.

\section{Penutup}

Berdasarkan hasil pembahasan di atas, penulis menyimpulkan, bahwa hubungan hukum antara induk perusahaan dan anak perusahaan merupakan hubungan affiliasi. Meski secara yuridis anak perusahaan merupakan unit perusahaan yang terpisah dan mandiri dari perusahaan induk (holding company), namun dalam hal anak perusahaan mengalami pailit maka holding company BUMN tetap dapat dimintai pertanggungjawaban. 
Kedua, apabila anak perusahaan mengalami kepailitan, maka holding company hanya bertanggungjawab sebatas saham yang dimiliki dalam anak perusahaannya. Hal ini karena keduanya adalah entitas hukum yang terpisah (separate legal entity). Namun, induk perusahaan dapat diminta pertanggungjawaban apabila dapat dibuktikan bahwa induk perusahaan turut menyebabkan kerugian terhadap suatu Persero yang merupakan anak perusahaannya (prinsip piercing the corporate veil).

Prinsip separate legal entity dalam sebuah perusahaan holding tentu menjadikan anak-anak perusahaan dalam hal ini anak perusahaan BUMN, bertanggung jawab secara terpisah. Akan tetapi, dikarenakan adanya saham BUMN dan unsur keuangan negara di dalam anak perusahaan baik secara langsung maupun tidak langsung, maka berpotensi sangat mengganggu kestabilan BUMN dan perekonomian negara. Sehingga perlu dikaji lebih mendalam mengenai hubungan hukum Perseroan, serta sejauh mana tanggung jawab induk perusahaan BUMN terhadap anak perusahaannya apabila terjadi kepailitan.

\section{Daftar Pustaka}

\section{Buku}

Fuady, Munir, Hukum Perusahaan Dalam Paradigma Hukum Bisnis, PT. Citra Aditya Bakti, Bandung, 1999.

Hartono, Sri Rejeki, Kapita Selekta Hukum Perusahaan, Mandar Maju, Bandung, 2000. Komaruddin, Ekonomi Perusahaan dan Manajemen, Alumni, Bandung, 2009.

Nating, Imran, Hukum Kepailitan, Puscaka Utama Grafiti, Bandung, 2002.

Marzuki, Peter Mahmud, Penelitian Hukum, Kencana Prenada Media Group, Jakarta, 2017.

Prasetya, Rudhi, Kedudukan Mandiri Perseroan Terbatas disertai dengan Ulasan Menurut Undang-Undang Nomor 1 tahun 1995, Cetakan Ketiga, Citra Aditya Bakti, Bandung, 2001.

Teori \& Praktik Perseroan Terbatas, Sinar Grafika, Jakarta, 2011.

Simanjuntak, Emmy Pangaribuan, Perusahaan Kelompok, Seksi Hukum Dagang Fakultas Hukum, Universitas Gajah Mada, Yogyakarta, 1996.

Sulistiowati, Tanggung Jawab Hukum Pada Perusahaan Grup di Indonesia, Erlangga, Jakarta, 2013.

Yani, Ahmad \& Gunawan Widjaja, Seri Hukum Bisnis Perseroan Terbatas, Raja Grafindo Persada, Jakarta, 1999. 


\section{Jurnal dan Tesis}

Adriano, Elvia A.Q., "The Natural Person, Legal Entity or Juridical Person and Juridical Personality", Penn State Journal of LawEInternational Affairs, Vol. 4, Issue 1 Seventeenth Biennal Meeting of The International Academy of Commercial and Consumer Law, 2015.

Khairandy, Ridwan, "Konsepsi Kekayaan Negara Dipisahkan Dalam Perusahaan Perseroan", Jurnal Hukum Bisnis, Vol. 26-No. 1, 2007.

Natun, Julio Thimotius Kapitan Smaud "Status Kepemilikan Anak Perusahaan BUMN", Mimbar Keadilan, Volume 12 Nomor 1, Februari 2019-Juli 2019.

Onakoya, Adegbemi Babatunde and Ayooluwa Eunice Olotu, "Bankcruptcy and Insolvency : An Exploration of Relevant Theories", International Journal of Economics and Financial Issue, Vol. 7, Issue 3, 2017.

Priangga, Rizal Widiya dan Yudho Taruno Muryanto, "Analisis Yuridis Sita Umum Aset Badan Usaha Milik Negara Terhadap Undang-Undang Nomor 1 Tahun 2004 tentang Perbendaharaan Negara", Jurnal Hukum, Vol. V, No. 1, 2009.

Rahadiyan, Inda, “Kedudukan BUMN Persero Sebagai Separate Legal Entity Dalam Kaitannya Dengan Pemisahan Keuangan Negara Dalam Permodalan BUMN", Jurnal Hukum Ius Quia Iustum, Vol. 20, No. 4, 2013.

Sipayung, Jhon F., "Tinjauan Yuridis Holdingisasi Bumn Dalam Rangka Peningkatan Kinerja Menurut Perspektif Hukum Perusahaan", TRANSPARENCY, Jurnal Hukum Ekonomi, Vol. I, No. 1, 2013.

Tanaya, Putu Edgar dan Kadek Agus Sudiarawan, “Akibat Hukum Kepailitan Badan Usaha Milik Negara Pasca berlakunya Undang-Undang Nomor 17 tahun 2003 tentang Keuangan Negara", Jurnal Hukum, Vol. 3, No. 1, 2017.

Tuti Muryati, Dewi, dkk., "Kajian Normatif Atas Kepailitan BUMN (Persero) Dalam Kaitannya Dengan Pengaturan Perseroan Terbatas", J. DINAMIKA SOSBUD, Vol. 17, No. 2, 2015.

Widawati, Rita Diah, Tanggung Jawab Induk Perusahaan Terhadap Perikatan Yang Dilakukakan Oleh Anak Perusahaan, Tesis, Program Magister Kenotariatan Universitas Sumatera Utara, Medan, 2009.

\section{Peraturan Perundang-Undangan}

Undang-Undang Nomor 19 Tahun 2003 tentang Badan Usaha Milik Negara Tambahan Lembaran Negara Republik Indonesia Nomor 4297.

Undang-Undang Nomor 40 Tahun 2007 tentang Perseroan Terbatas Tambahan Lembaran Negara Republik Indonesia Nomor 4756.

Undang-Undang Nomor 37 Tahun 2004 tentang Kepailitan dan Penundaan Kewajiban Pembayaran Utang Tambahan Lembaran Negara Republik Indonesia Nomor 4443.

Peraturan Pemerintah Nomor 72 Tahun 2016 tentang Perubahan Atas Peraturan Pemerintah Nomor 44 Tahun 2005 tentang Tata Cara Penyertaan dan 
Penatausahaan Modal Negara pada Badan Usaha Milik Negara Tambahan Lembaran Negara Republik Indonesia Nomor 6006.

Peraturan Menteri Negara Badan Usaha Milik Negara Nomor : Per- 09 /Mbu/2012 Tentang Perubahan Atas Peraturan Menteri Negara Badan Usaha Milik Negara Nomor Per-01/Mbu/2011 tentang Penerapan Tata Kelola Perusahaan Yang Baik (Good Corporate Governance) Pada Badan Usaha Milik Negara.

Peraturan Menteri BUMN Nomor 3 Tahun 2012 tentang Pedoman Pengangkatan Anggota Direksi Dan Anggota Dewan Komisaris Anak Perusahaan Badan Usaha Milik Negara.

\section{Internet}

Definition Holding Company, http://www.businessdictionary.com/definition/ holding-company.html diakses pada 10 Oktober 2018.

Harshit Saxena, Lifting of Corporate Veil, http://ssrn.com/abstract=1725433, diakses pada 26 Mei 2019.

Holding Company, HoldingCompany https://www.investopedia.com/terms / h/holdingcompany.asp\#ixzz5TgCxsSOA diakses pada 11 Oktober 2018.

Isu Monopoli dan Kepailitan di Tengah Holding BUMN Tambang, http:/ / www.hukumonline.com/berita/baca/lt5a376d99c3672/isumonopoli-dan-kepailitan-di-tengah-holding-bumn-tambang diakses pada 10 Oktober 2018.

Shi Jianzhong, Insolvency of Groups: Problem Involving Parent Companies and Their Affiliates, http:/ / www.law.hku.hk/aiifl/wp-content/uploads/2014 /07/2000_nov_shi jianzhong.doc , diakses pada 20 November 2018.

Status Hukum Anak Perusahaan BUMN, https://www.hukumonline.com/ klinik/detail/lt50629054c7269/status-hukum-anak-perusahaan-bumn diakses pada 10 September 2018.

Practical Law, Parent Entity Liability in Insolvency, https://uk.practicallaw. thomsonreuters.com/85667187?transitionType=Default\&contextData=(sc. Default)\&firstPage $=$ true \&comp $=$ pluk\&bhcp $=1$, diakses pada 15 Desember 2018. 